\title{
Translational medical research in Nigeria: challenges, prospects and recommendations for the future
}

\author{
Afeez Salami ${ }^{1}$, Kehinde Kazeem Kanmodi ${ }^{2,3}$ \\ ${ }^{1}$ Department of Oral and Maxillofacial Surgery, University College Hospital, Ibadan, Nigeria \\ ${ }^{2}$ Medical Research Unit, Adonai Hospital, Karu, Nigeria \\ ${ }^{3}$ Office of the Executive Director, Cephas Health Research Initiative Inc, Ibadan, Nigeria
}

\begin{abstract}
In this review we discussed the challenges and prospects for translational medical research in Nigeria, a developing African country. We also provided some relevant recommendations on how to improve the future of translational medical research in the Nigeria.
\end{abstract}

Keywords: translational medical research $\cdot$ challenges $\cdot$ prospects $\cdot$ recommendations $\cdot$ Nigeria

\section{Citation}

Salami A, Kanmodi KK. Translational medical research in Nigeria: challenges, prospects and recommendations for the future. Eur J Transl Clin Med. 2021;4(1):71-78.

DOI: $10.31373 /$ ejtcm/133109

\section{Introduction}

Translational medical research is the process of applying knowledge from basic biology and clinical trials to techniques and tools that address critical medical needs [1]. The concept of translational medical research is hinged on ethical, systematic and purposeful enquiries into nature [2]. This inherent complexity leads researchers in this field of translational medicine to face various challenges. These challenges are noteworthy, ubiquitous and capable of affecting the quality of a translational medical research project. Some of these challenges include poor funding to lack of functional equipment to poor political will, inadequate international exposures/collaborations or unfavorable bureaucracies, just to mention a few [3]. It is noteworthy that many of the above-mentioned challenges are more evident in developing nations when compared

Corresponding author:

Kehinde Kazeem Kanmodi, Medical Research Unit, Adonai Hospital, Karu, Nigeria;

Office of the Executive Director, Cephas Health Research Initiative Inc, Ibadan, Nigeria

e-mail: kanmodikehinde@yahoo.com

No external funds.

Available online: www.ejtcm.gumed.edu.pl

$\underset{\substack{\text { TRANSPARENT } \\ \text { PROCESS }}}{0}$

Copyright $®$ Medical University of Gdańsk

This is Open Access article distributed under the terms of the Creative Commons Attribution-ShareAlike 4.0 International. 
to the developed world [3-4]. In this narrative review, we aimed briefly discuss the notable and historical achievements of translational medical research in $\mathrm{Ni}$ geria and beyond and also to examine the prospects and challenges of conducting translational medical research in Nigeria - a typical developing African country.

\section{Materials and methods}

This study was a narrative review of relevant medical literature about the history, prospects, challenges and conducts of translational medical research in $\mathrm{Ni}$ geria. We searched the following research databases: Google Scholar, PubMed, ResearchGate, SCOPUS, ClNAHL, PsycINFO and AJOL.

\section{Notable achievements in the field of transla- tional medical research in Nigeria and beyond}

Over the years, many problems had been solved worldwide through translational medical research [5-10]. For example, the discovery of insulin by Frederick Banting in 1922 radically changed the medical management of the then-notoriously deadly diabetes mellitus [6]. Paul Ehrlich's discovery of the first chemotherapeutic drug revolutionized the field and clinical practice of oncology [7]. The discovery of penicillin by Sir Alexander Fleming increased the effectiveness of bacterial infection treatment [8]. The ground-breaking research on human blood circulation by William Harvey was the foundation for countless innovation in physiology and cardiology [9]. Karl Landsteiner's discovery of human blood groups revolutionized the concept of blood transfusion [10]. These and many more are notable humanitarian achievements made by translational medical researchers.

In Nigeria, the practice of medical research commenced in 1920 with the arrival of the Rockefeller Foundation and the Yellow Fever Commission [11]. Over the years, academic and/or research institutions like the University of Ibadan (1948), the University College Hospital as well as other universities and tertiary health care facilities were established. These institutions continue to "produce" local and international researchers in all fields of study including medical sciences. For example, Professor Temidayo O. Ogundiran is best known for his translational medical research on breast cancer among African women [12], Professor Adesola Ogunniyi pioneered translational research on dementia in the sub-Saharan Africa [13], and Professor Lanre Wasiu Adeyemo is nationally known for his translational research contribution in the area of genetics of orofacial clefts [14]. The research output of these researchers have significantly contributed to the field of translational medicine in Nigeria and beyond [12-14]. At the moment, many notable translational medical research projects are on-going in Nigeria; hence, translational medical research has come to stay in Nigeria.

\section{Challenges facing translational medical re- search in Nigeria}

As mentioned earlier, translational medical research has globally revolutionized the practice of medicine. However, the conduct of translational medical research is more challenging in the developing countries due to some peculiar problems such as lack of funding and functional equipment, unfavorable policies and practices, inadequate international exposures as well as lack of political will [3, 15-20]. However this is not the case in developed countries (e.g. the United States of America, United Kingdom etc.) where there is relative ease in conducting research [21-22] - this ease is partly due to the availability of support system through funding, mentoring and collaborations.

Despite the huge contributions of translational medical research toward the prevention, diagnosis, investigation and management of different medical conditions in Nigeria [12-14], conducting such research endeavor in Nigeria is quite difficult due to enormous challenges [13]. The causes of this situation can be grouped into human, environmental and other non-human resource factors [15-16], all of which are discussed below.

\section{A. Environmental and non-human resource factors}

Environmental and non-human resource factors [15] in conducting translational medical research in Nigeria center on the environment where researchers work as well as the non-human resources needed for such endeavor. Below are common factors of such in Nigeria:

\section{Inadequate funding}

Funding is a very important aspect of translational medical research. Unfortunately, Nigeria spends a very low percentage $(0.2-0.4 \%)$ of its gross domestic product (GDP) on research and development projects [23]. Most medical researchers in Nigeria fund their projects out of pocket due to massive lack of financial support from the Nigerian government and private institutions [24-25]. The reagents, equipment, consumables and other materials needed for translational medical research, often times are capital-intensive. 
Therefore, it is usually (if not always) distressing for medical researchers to find support for novel research projects. Self-funding sometimes impedes the progress of their research project or causes them to outright abandon it.

\section{Embezzlement and other corrupt practices}

Embezzlement and other corrupt practices (such as bribery) are common practices in many African countries. Particularly in Nigeria these practices are also found in the medical research institutes and tertiary healthcare institutions [26]. It is therefore worthy of note that funds meant for research are being embezzled or short-sized along the chain of disbursement. Research funding is more often than not embezzled by government officials or institute managers for bribery and other personal benefits. These unethical practices certainly leave the researchers with far less funds to support their projects and certainly deters advances in translational medical research $[17,20]$.

\section{High cost of modern medical equipment and ma- intenance}

Due to the perpetual inflation of Nigeria's currency (naira) [27], the cost of modern medical equipment is rising annually. The persistently high cost of modern medical equipment (as well as all reagents) and maintenance makes much of the equipment unaffordable. If they are eventually acquired, the spare parts or skilled personnel needed for their maintenance or repair are not easily accessible, once again due to high costs.

This problem frequently limits the progress or completely halts a translational medical research or adversely affects its quality or outcomes. For example, the use of immunohistochemistry techniques in the diagnosis of cancerous cells and in the expression of proteins in biological samples is a rare practice in Nigeria due to heavy financial implications associated with such medical procedures. This specific problem has affected many immunology researchers in Nigeria and the laboratory diagnosis of cancer cells is limited to the use of the hematoxylin and eosin stains. Furthermore, the use of modern diagnostic equipment such as computer tomography or magnetic resonance imaging is unavailable in most of the tertiary healthcare facilities in Nigeria. Where they are available, their level of maintenance is very poor, leading to their abandonment. This situation can be very frustrating both to clinicians performing patient care and to translational medical researchers who need to use this equipment for a collaborative research project.

\section{Unavailability of advanced computer technology/ information technology}

The unavailability of advanced computer technology and quality information technology in many Nigerian research institutions create additional limitations for translational medical researchers in Nigeria [28]. For example, the availability of reliable institution-provided internet services is grossly limited. Therefore, many people in Nigeria, including researchers, rely on mobile data services for access to the internet. Unfortunately, the mobile data services in Nigeria are very unreliable and irregular. As a result, Nigerian translational medical researchers have a barrier to keeping up with scientific developments due to limited access to online journals, books, electronic data bases and forum discussions [28-29].

\section{Unfavorable institutional policies and practices}

The policies and practices within the institutions in Nigeria also impede translational medical research [24, 30-31]. Some institutional policies limit the access to research laboratories unless with the approval of heads of department, deans of faculties, etc. This may limit early career researchers from carrying out independent medical research projects [30-31]. However, in some situations junior medical researchers involved their senior coworkers in their translational medical research projects only to have the project hijacked. This practice is obviously unethical and must be abolished in the Nigerian medical research settings.

\section{Government priorities}

The priorities of the Nigerian government and its institutions have shifted away from funding research (including translational) and healthcare and now are focused on food availability, improving security and abolishing corruption [25, 27]. It has therefore become an uphill task for Nigerian scientists to access funding for translational research projects. The low level of priority given to research by the Nigeria government is quite worrisome because we observed that this shift in priorities is not a universal practice among African countries. In fact, non- or less-oil rich nations like Mozambique, Tanzania, Malawi and Uganda spend $\geq 0.4 \%$ of their GDP on research and development (compared to Nigeria with $0.2-0.4 \%$ of its GDP) [23].

\section{B. Human Factors}

The commitment of the individual carrying out a medical research project plays a very crucial role in the outcome of such project. The human factors affecting medical research are mentioned below. 


\section{Lack of interest/motivation}

Some medical researchers in Nigeria often engage in research only for the purpose of promotion and many of them stop publishing once they reach the zenith of the promotion ladder. In order to advance their careers, some of these researchers engage in unethical practices e.g. plagiarism, falsification or outright fabrication of data [30-32]. Many are only interested in climbing the promotion ladder for financial benefits. Furthermore, some senior medical researchers sometimes edit and publish the research works of their undergraduate students without giving proper authorship credit after publication. This is another common unethical practice and it further underscores their lack of interest in contributing to knowledge through original efforts.

\section{Inadequate mentoring}

Mentoring and counseling of medical science students/trainees at both undergraduate and postgraduate levels has been neglected or even abused at many Nigerian tertiary institutions [24, 33]. Specifically, the relationship between the students and their lecturers is more of a master-servant, instead of the required mentor-mentee. In fact, some lecturers who supervise final year projects and research of students frustrate the students involved either by being unnecessarily unavailable or not showing enough leadership in encouraging their students. In view of this, many undergraduates conclude that research is not intended for them and therefore fail to learn this art early in their career. Therefore, undergradiates complete their final year research project for the purpose of scoring marks and not to prepare themselves for engaging in research and contributing to medical knowledge. In sum, a proper mentor-mentee relationship can go a long way in encouraging the young generation to get involved in translational research $[24,33]$.

\section{Lack of local and international exposure and col- laboration}

Collaboration and exposure also play a role in the quest for translational medical research [24]. A lack of either of these factors limits the robustness of translational medical research projects. Many at times, translational medical research involves collaborations and wide horizon of exposure; these two factors are vital when it comes to harnessing one's strength in translational medical research for obtaining holistic results. Unfortunately, many Nigerian medical researchers lack these two factors/opportunities [24].

\section{Deficient English language proficiency}

English language proficiency (especially writing) is an important skill for the translational medical resear- cher [34]. Unfortunately, quite many Nigerian researchers are not proficient in the English language which is a barrier between them and the reviewers of their manuscript as well as their target audience. The numerous grammatical errors seen in the research papers of many Nigerian medical researchers are capable of distorting the reviewers' and readers' understanding of the methodology and outcomes of the described projects.

\section{Prospects for translational medical re- search in Nigeria}

As massive and discomforting the above-described challenges may appear, there are still many prospects. A look at the history of translational medical research in Nigeria underscores the fact that despite all the challenges, this field of research can and should be continuously explored in order to promote health care and wellness. There are several topics of medical science that still require exploration, regardless of these above-mentioned challenges, some of which are mentioned below.

\section{A. Highly infectious diseases}

The emergence of highly infectious diseases (e.g. the current SARS-CoV-2 infections, Lassa fever, Ebola viral disease, HIV/AIDS etc.), require more research in order to control spread, manage and treat the condition, to educate the population and to implement effective prevention strategies. The COVID-19 pandemic is a revelation of how much we need to intensify our efforts in conducting in-depth translational research projects on epidemic-prone infectious diseases [35]. The need for a comprehensive understanding of the mode of spread, rapid diagnosis via dedicated kits, vaccines and curative treatment will require a lot of translational medical research efforts and this is a significant opportunity for live-saving medical research in Nigeria.

\section{B. Increasing incidence and prevalence of neo- plasms}

The etiology, pathogenesis, diagnosis and management of neoplasms (particularly of the head and neck, cervical cancer and breast cancer) are also key topics to explore in the Nigerian population through translational medical research. The reason is rather evident: the persistently rising rates of neoplasm-associated morbidities and mortalities in Nigeria [36-38].

\section{Increasing incidence of mental disorders}

Mental disorders such as depression, substance abuse or anxiety disorders have an estimated inciden- 
ce of about $20-30 \%$ of the Nigerian population [39-41]. This rate is alarming and should stimulate more translational medical research in order to hopefully answer many current questions about the causes and effective treatment/prevention of these disorders. It seems that through rigorous translational medical research that informs policy and medical practice, the burden of the psychological disorders in Nigeria can be significantly reduced.

D. Increasing incidence of hypertension, diabetes and other non-communicable diseases

Non-communicable diseases such as hypertension or diabetes are also an area of significant prospects for translational medical researchers in Nigeria. The persistently rising trend of unhealthy behaviors (unsafe sexual practices, use of tobbacco, alcohol and other psychoactive substances) among young Nigerians is worthy of note. It is up to the reasearchers to explore the influence of the above-mentioned behaviors of on the persistent rise in the incidence rates of hypertension, diabetes and other diseases in Nigeria [42].

\section{Recommendations for the future}

Having mentioned several challenges and prospects of translational medical research in Nigeria we attempted to make several recommendations for the future of translational medical research in Nigeria.

\section{A. Improvement of Funding for Translational Medical Research}

An improvement in funding will go a long way in reducing several of the above-mentioned barriers to conducting translational medical research in Nigeria. These funds could be provided as grants, donations or interventions. The availability of funding will also serve as motivation for Nigerian medical researchers.

Also, as a way of reducing costs of translational research projects, Nigerian scientists should consider the following options (list not exhaustive):

I. publishing research articles in reputable journals that do not charge the authors any fees (article processing charges),

II. recruitment of enthusiastic and qualified persons who are willing to work as laboratory or research assistants on a volunteer basis,

III. engagement in group collaboration such that the financial burden of the research project can be shared among the participating researchers,

IV. applying for research funding from foreign sources.

\section{B. Dedicated research institutions}

Encouragement and improving the environment to practice translational medical research in Nigeria can be achieved by provision of special research institutions e.g. the national dental institute, infectious disease research laboratories or cardiovascular research institution to promote research and train researchers. This can be achieved through the contribution of interested non-governmental organizations or governmental institutions or agencies. Certainly there must be significant commitment to the sustainability of such facility in order for this strategy to succeed.

\section{Mentorship}

The re-vitalization of mentorship programs in the tertiary institutions is highly desired. Students who are enthusiastic about translational research should be encouraged (and given an opportunity to do so) via proper mentor-mentee relationship. They should be motivated by getting the authorship credit for research articles, chapters, books, reviews they contributed to.

\section{International exposure}

The need for international exposure among medical researchers in Nigeria is also essential. The curriculum of the undergraduate and postgraduate medical training should be expanded to accommodate international exposure through outside postings and exchange programs. This will make collaboration with colleagues abroad easy and is likely to improve the $\mathrm{Ni}$ gerian researchers' output.

\section{E. Implementing favorable policies and practices}

The era of junior medical researchers being restricted by policy to their supervisors' permission should be thrown into the bin of history. Many young medical researchers were forced to bury their dreams of conducting potentially ground-breaking translational research due to lack of approval from their superiors. We suggest that once a junior researcher's research proposal obtains approval from the local ethical committee/board, there should be no other reason (such as objection from the supervisor) for not cconducting that study. The policies that currently dominate Nigerian research institutions should be completely abolished and be substituted with favorable ones.

\section{F. Regular training and re-training of personnel}

Sometimes, the procurement of scientific equipment is easier than assuring the its proper maintenance. Researchers using the equipment as well as the technicians who repair it should not engage in trial 
\& error attempts and thereby underutilize or disrupt their function. In order to remove this barrier to translational research, we recommend that sufficient funds are expertise are reserved for training and re-training of all research staff.

\section{G. English language proficiency among researchers}

As earlier mentioned, poor English communication skills among medical researchers in Nigeria is a serious problem. In order to mitigate it, medical researchers should have take dedicated English language lessons and tests. This will make medical research outcomes well-understood by reviewers and the readers. We also recommend that the Nigerian government should fund opportunities for professional training and mentorship on scientific writing for researchers.

\section{Conclusion}

In order for Nigeria to achieve significant and sustained improvement in healthcare, it needs to allocate a greater percentage of its GDP for research. Currently there is a significant and urgent need for well-planned investment in translational medical research in Nigeria.

Author's contributions: Both authors contributed equally to the study.

Funding: This study was self-funded.

Conflicts of interest: Authors have none to declare.

\section{References}

1. What is Translational Research? [Internet]. UCDavis. [cited 2021 Feb 8]. Available from: https://www.ucdavis.edu/onehealth/translational-research/\#: :text=Translational research is the process, designed to improve health outcomes

2. Slowther A. Research governance: ethical issues. J R Soc Med [Internet]. 2006 Feb 1;99(2):65-72. Available from: http:// www.jrsm.org/cgi/doi/10.1258/irsm.99.2.65

3. Zhou L, Li Y, Bosworth HB, Ehiri J, Luo C. Challenges facing translational research organizations in China: a qualitative multiple case study. J Transl Med [Internet]. 2013;11(1):256. Available from: http://translational-medicine.biomedcentral. com/articles/10.1186/1479-5876-11-256

4. Yao Q, Lyu P-H, Ma F-C, Yao L, Zhang S-J. Global informetric perspective studies on translational medical research. BMC Med Inform Decis Mak [Internet]. 2013 Dec 26;13(1):77. Available from: http://bmcmedinformdecismak. biomedcentral. com/articles/10.1186/1472-6947-13-77

5. Dragani TA, Castells A, Kulasingam V, Diamandis EP, Earl H, lams WT, et al. Major milestones in translational oncology. BMC Med [Internet]. 2016 Dec 28;14(1):110. Available from: http://bmcmedicine.biomedcentral.com/articles/10.1186/ s12916-016-0654-y

6. Frederik Grant Banting (1891-1941) Codiscoverer of insulin. JAMA J Am Med Assoc [Internet]. 1966 Nov 7;198(6):660.

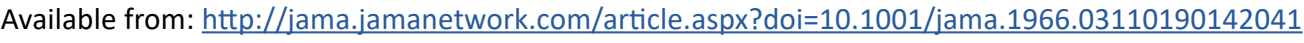

7. Piro A, Tagarelli A, Tagarelli G, Lagonia P, Quattrone A. Paul Ehrlich: The Nobel Prize in Physiology or Medicine 1908. Int Rev Immunol [Internet]. 2008 Jan 3;27(1-2):1-17. Available from: http://www.tandfonline.com/doi/ full/10.1080/08830180701848995

8. Tan S, Tatsumura Y. Alexander Fleming (1881-1955): Discoverer of penicillin. Singapore Med J [Internet]. 2015 Jul;56(07):366-7. Available from: http://www.smj.org.sg/article/alexander-fleming-1881-1955-discoverer-penicillin

9. Friedland G. Discovery of the function of the heart and circulation of blood. Cardiovasc J Afr [Internet]. 2009;20(3):160. Available from: http://www.ncbi.nlm.nih.gov/pubmed/19575077

10. Farhud DD, Zarif Yeganeh M. A brief history of human blood groups. Iran J Public Health [Internet]. 2013;42(1):1-6. Available from: http://www.ncbi.nlm.nih.gov/pubmed/23514954

11. Learning M, Cookbook R. The Rockefeller Foundation Annual Report 1926 [Internet]. New York; 1927. Available from: https://www.rockefellerfoundation.org/wp-content/uploads/Annual-Report-1926-1.pdf

12. Prof. Temidayo O. OGUNDIRAN [Internet]. College of Medicine, University of Ibadan. [cited 2021 Feb 8]. Available from: http://com.ui.edu.ng/academicstaff-details/146

13. Professor Ogunniyi: Dementia Research Pioneer in sub-Saharan Africa [Internet]. SciCom Nigeria. [cited 2021 Feb 8]. Available from: https://www.scicomnigeria.org/article/Professor-Ogunniyi\%3A-Dementia-Research-Pioneer-in-sub-Saharan-Africa

14. Alao A. Professor Wasiu Lanre Adeyemo, Others Win 2018 NAS Gold Medal Prize of Science - Edugist [Internet]. EduGist. 2019 [cited $2021 \mathrm{Feb} 8$ ]. Available from: http://edugist.org/professor-wasiu-lanre-adeyemo-others-win-2018-nas-goldmedal-prize-of-science/ 
15. Badr MZ. Challenges Facing Scientific Research in Developing Countries: 2. Environment and Resources. Egypt J Basic Clin Pharmacol [Internet]. 2018;8. Available from: http://www.kenzpub.com/journals/ejbcp/2018/101388/

16. Badr MZ. Challenges Facing Scientific Research in Developing Countries: 1. The Human Factor. Egypt J Basic Clin Pharmacol [Internet]. 2018;8. Available from: http://www.kenzpub.com/journals/ejbcp/2018/101378/

17. Merkle O. Corruption risks in research funding in developing countries [Internet]. 2017 [cited 2021 Feb 8]. Available from: https://www.u4.no/publications/corruption-risk-research-funding.pdf

18. Vose PB, Cervellini A. Problems of scientific research in developing countries. IAEA Bull [Internet]. 1981 [cited 2021 Feb 8];25(2):37-40. Available from: https://www.iaea.org/sites/default/files/publications/magazines/bulletin/bull252/25205383740.pdf

19. Bennett NR, Cumberbatch C, Francis DK. There are challenges in conducting systematic reviews in developing countries: the Jamaican experience. J Clin Epidemiol [Internet]. 2015 Sep;68(9):1095-8. Available from: https://linkinghub.elsevier. com/retrieve/pii/S0895435615000608

20. Amerson RM, Strang CW. Addressing the Challenges of Conducting Research in Developing Countries. J Nurs Scholarsh [Internet]. 2015 Nov;47(6):584-91. Available from: http://doi.wiley.com/10.1111/inu.12171

21. Sussex J, Feng Y, Mestre-Ferrandiz J, Pistollato M, Hafner M, Burridge P, et al. Quantifying the economic impact of government and charity funding of medical research on private research and development funding in the United Kingdom. BMC Med [Internet]. 2016 Dec 24;14(1):32. Available from: http://www.biomedcentral.com/1741-7015/14/32

22. Hather GJ, Haynes W, Higdon R, Kolker N, Stewart EA, Arzberger P, et al. The United States of America and Scientific Research. Valdes-Sosa PA, editor. PLoS One [Internet]. 2010 Aug 16;5(8):e12203. Available from: https://dx.plos. org/10.1371/journal.pone.0012203

23. Simpkin V, Namubiru-Mwaura E, Clarke L, Mossialos E. Investing in health R\&D: where we are, what limits us, and how to make progress in Africa. BMJ Glob Heal [Internet]. 2019 Mar 4;4(2):e001047. Available from: https://gh.bmj.com/ lookup/doi/10.1136/bmigh-2018-001047

24. Ezeanolue EE, Menson WNA, Patel D, Aarons G, Olutola A, Obiefune M, et al. Gaps and strategies in developing health research capacity: experience from the Nigeria Implementation Science Alliance. Heal Res Policy Syst [Internet]. 2018 Dec 12;16(1):10. Available from: https://health-policy-systems.biomedcentral.com/articles/10.1186/s12961-018-0289-x

25. Uzochukwu B, Mbachu C, Onwujekwe O, Okwuosa C, Etiaba E, Nyström ME, et al. Health policy and systems research and analysis in Nigeria: examining health policymakers' and researchers' capacity assets, needs and perspectives in southeast Nigeria. Heal Res Policy Syst [Internet]. 2016 Dec 24;14(1):13. Available from: http://www.health-policy-systems. com/content/14/1/13

26. Onwujekwe O, Agwu P, Orjiakor C, McKee M, Hutchinson E, Mbachu C, et al. Corruption in Anglophone West Africa health systems: a systematic review of its different variants and the factors that sustain them. Health Policy Plan [Internet]. 2019 Sep 1;34(7):529-43. Available from: https://academic.oup.com/heapol/article/34/7/529/5543565

27. Alloh FT, Regmi PR. Effect of economic and security challenges on the Nigerian health sector. Afr Health Sci [Internet]. 2017 Jul 17;17(2):591. Available from: https://www.ajol.info/index.php/ahs/article/view/158755

28. Ajuwon GA. Use of the Internet for health information by physicians for patient care in a teaching hospital in Ibadan, Nigeria. Biomed Digit Libr [Internet]. 2006 Dec 12;3(1):12. Available from: https://bio-diglib.biomedcentral.com/articles/10.1186/1742-5581-3-12

29. Bello IS, Arogundade FA, Sanusi AA, Ezeoma IT, Abioye-Kuteyi EA, Akinsola A. Knowledge and Utilization of Information Technology Among Health Care Professionals and Students in Ile-Ife, Nigeria: A Case Study of a University Teaching Hospital. J Med Internet Res [Internet]. 2004 Dec 17;6(4):e45. Available from: http://www.jmir.org/2004/4/e45/

30. Okonta P, Rossouw T. Prevalence of Scientific Misconduct Among a Group of Researchers in Nigeria. Dev World Bioeth [Internet]. 2013 Dec;13(3):149-57. Available from: http://doi.wiley.com/10.1111/i.1471-8847.2012.00339.x

31. Adeleye OA, Adebamowo CA. Factors Associated with Research Wrongdoing in Nigeria. J Empir Res Hum Res Ethics [Internet]. 2012 Dec;7(5):15-24. Available from: http://journals.sagepub.com/doi/10.1525/jer.2012.7.5.15

32. Lawal I. Nigerian universities and the plague of plagiarism [Internet]. The Guardian Nigeria News - Nigeria and World News. 2019 [cited 2021 Feb 8]. Available from: https://guardian.ng/features/nigerian-universities-and-the-plague-of-plagiarism/

33. Iloh GP, Chukwuonye M, Onya O, Godswill-Uko E. Mentoring in a resource-constrained context: A single-institutional cross-sectional study of the prevalence, benefits, barriers and predictors among post-graduate medical college fellows and members in South-Eastern Nigeria. Niger Postgrad Med J [Internet]. 2019;26(1):38. Available from: http://www. npmj.org/text.asp?2019/26/1/38/253977 
34. Kumwenda S, Niang EHA, Orondo PW, William P, Oyinlola L, Bongo GN, et al. Challenges facing young African scientists in their research careers: A qualitative exploratory study. Malawi Med J [Internet]. 2017 May 3;29(1):1. Available from: https://www.ajol.info/index.php/mmj/article/view/155437

35. Smiatacz T. It didn't have to happen this way - what COVID-19 tells us about translational medicine. Eur J Transl Clin Med [Internet]. 2020 May 29;3(1):7-10. Available from: https://ejtcm.gumed.edu.pl/articles/60

36. Adamu PI, Adamu MO, Okagbue HI, Opoola L, Bishop SA. Survival Analysis of Cancer Patients in North Eastern Nigeria from 2004 - 2017 - A Kaplan - Meier Method. Open Access Maced J Med Sci [Internet]. 2019 Feb 22;7(4):642-9. Available from: https://spiroski.migration.publicknowledgeproject.org/index.php/mjms/article/view/oamjms.2019.109

37. Mohammed A, Edino S, Ochicha O, Gwarzo A, Samaila A. Cancer in Nigeria: A 10-Year Analysis of the Kano Cancer Registry. Niger J Med [Internet]. 2008 Sep 16;17(3). Available from: http://www.ajol.info/index.php/njm/article/view/37396

38. Nggada HA, Yawe K-DT, Abdulazeez J, Khalil MA. Breast Cancer Burden in Maiduguri, North Eastern Nigeria. Breast J [Internet]. 2008 May;14(3):284-6. Available from: http://doi.wiley.com/10.1111/j.1524-4741.2008.00576.x

39. Onyemelukwe C. Stigma and mental health in Nigeria: Some suggestions for law reform. J Law Policy Glob [Internet]. 2016;55:63-8. Available from: https://core.ac.uk/download/pdf/234650863.pdf

40. WHO and Ministry of Health. WHO-AIMS Report on Mental Health System in Nigeria. Minist Heal Niger [Internet]. 2006;7(September):79-92. Available from: https://www.who.int/mental health/evidence/nigeria who aims report.pdf.

41. Mental Health Situation Analysis in Nigeria [Internet]. MHLAP. 2012 [cited 2021 Feb 8]. Available from: http://www. mhlap.org/idownloads/mhlap 2012/mental health situation analysis in nigeria.doc.

42. Steyn K, Damasceno A. Lifestyle and Related Risk Factors for Chronic Diseases. In: Disease and Mortality in Sub-Saharan Africa 2nd ed [Internet]. The International Bank for Reconstruction and Development / The World Bank; 2006 [cited 2021 Feb 8]. p. 247-65. Available from: http://www.ncbi.nlm.nih.gov/pubmed/21290651 